\title{
KEJADIAN PNEUMONIA PADA BATITA DI WILAYAH KERJA PUSKESMAS SUKAMERINDUKOTA BENGKULU
}

\author{
Lela Hartini dan Ismiati \\ Politeknik Kesehatan Kementerian Kesehatan Bengkulu, Jurusan Kebidanan, \\ Jalan Indragiri Nomor 03 Padang Harapan Kota Bengkulu \\ Ismiatidzaky@gmail.com
}

\begin{abstract}
Pneumonia is an infection or inflammation of the lower respiratory tract that involves the alveoli and bronchioles. Risk factors for pneumonia which occurs in boys aged 1-3 years with a skinny body weight. Pneumonia is the leading cause of death of infants and toddlers in Indonesia with a total percentage (23.6\%), which is the largest proportion of all-cause mortality in infants and toddlers. In the city of Bengkulu number of events in 2014 pneumonia were 942 (6.07\%), Sukamerindu health centre is first order with 51 people, Basuki Rahmat 47 people, and 39 people in Lingkar Barat. Purpose of this study was to determine the incidence of pneumonia in toddlers picture in Puskesmas Sukamerindu in 2014. This study used a descriptive design, with a population of children aged 1-3 years which amounted to 51 people, technique data sampling was used Total Sampling, data collection secondary techniques, data obtained by existing records in health centers (patient registers). The results showed that the majority $(60.8 \%)$ children aged 13-24 months, the majority (72.5\%) child-sex male, and most (56.9\%) children were in the category of lean body weight. It is recommended to parents, especially mothers to be able to take precautions against the occurrence of pneumonia, such as providing adequate nutrition to children so that children are not malnourished which can increase the risk of pneumonia
\end{abstract}

Keywords: toddler, Characteristics, Pneumonia

\begin{abstract}
Abstrak : Pneumonia merupakan infeksi atau inflamasi saluran pernapasan bawah yang melibatkan alveolus dan bronkiolus. Faktor resiko terjadi pneumonia yaitu pada anak laki-laki usia 1-3 tahun dengan berat badan kurus. Pneumonia merupakan penyebab kematian bayi dan balita terbesar di Indonesia dengan persentase sebanyak $(23,6 \%)$, yang merupakan proporsi terbesar dari seluruh penyebab kematian pada bayi dan balita. Di kota Bengkulu jumlah kejadian Peneumonia tahun 2014 sebanyak 942 (6,07\%), Puskesmas Sukamerindu merupakan urutan pertama yaitu 51 orang, Basuki Rahmat 47 orang, dan Lingkar barat 39 orang . Tujuan penelitian ini adalah mengetahui karakteristik kejadian Pneumonia pada batita di Wilayah Kerja Puskesmas Sukamerindu tahun 2014. Penelitian ini menggunakan desain deskriptif, dengan populasi anak usia 1-3 tahun yang berjumlah 51 orang, teknik pengambilan sampel secara total sampling, pengumpulan data dengan teknik sekunder yaitu data yang diperoleh dari catatan yang ada di Puskesmas (register pasien). Hasil penelitian menunjukkan bahwa sebagian besar $(60,8 \%)$ anak berumur 13-24 bulan, sebagian besar $(72,5 \%)$ anak berjenis kelamin laki-laki, dan sebagian besar $(56,9 \%)$ anak berada dalam kategori berat badan kurus. Disarankan kepada orang tua terutama ibu untuk dapat melakukan pencegahan terhadap terjadinya pneumonia, seperti memberikan nutrisi yang cukup pada anak agar anak tidak mengalami malnutrisi yang dapat meningkatkan resiko terjadinya pneumonia
\end{abstract}

Kata kunci : Batita, Karakteristik, Pneumonia

Menurut United Nations International Children Education Federation (UNICEF) penyebab kematian balita antara lain pneumonia yang merupakan urutan teratas dengan jumlah 2 juta balita meninggal setiap tahunnya. Lebih dari $98 \%$ kematian di akibatkan pneumonia yang terjadi di 68 negara sehingga pneumonia menjadi pembunuh nomor satu pada balita (WHO, 2010). 
Pneumonia merupakan penyakit sebagai penyebab kematian bayi dan balita terbesar di Indonesia dengan persentase sebanyak $(23,6 \%)$ kematian pada bayi dan balita disebabkan oleh penyakit ini, yang merupakan proporsi terbesar dari seluruh penyebab kematian pada bayi dan balita (Kemenkes, 2011).

Pneumonia merupakan infeksi atau inflamasi saluran pernapasan bawah yang melibatkan alveolus dan bronkiolus (Prawirohardjo, 2009). Faktor resiko terjadi pneumonia yaitu pada anak laki-laki usia 1-5 tahun, terutama pada usia 1-3 tahun karena pada masa tumbuh kembang ini anak rentan terhadap infeksi dan ancaman penyakit dari lingkungan serta maturasi serebral yang terjadi lebih cepat pada anak perempuan dibandingkan pada anak laki-laki (Depkes, RI 2009).

Faktor penyebab terjadinya pneumonia pada bayi dan balita disebabkan oleh status gizi (berat badan), kelengkapan imunisasi DPT, kondisi ekonomi, ASI, lingkungan, dan riwayat persalinan (KPD) (Depkes, 2009). Faktor status gizi yang dipengaruhi oleh berat badan khususnya pada anak yang malnutrisi, yang berakibat menurunya kekebalan tubuh anak terhadap penyakit (infeksi) baik yang disebabkan oleh virus, bakteri maupun fungi (Cuningham, 2006).

Tujuan penelitian ini adalah mengetahui karakteristik kejadian Pneumonia pada batita di Wilayah Kerja Puskesmas Sukamerindu tahun 2014.

\section{BAHAN DAN CARA KERJA}

Penelitian ini merupakan penelitian deskriptif. Penelitian dilakukan di Puskesmas Sukamerindu. Populasi dalam penelitian ini adalah anak usia 1-3 tahun yang menderita pneumonia pada tahun 2014 sebanyak 51 orang. Sample diambil menggunakan teknik total sampling, dimana seluruh anggota populasi menjadi sampel dalam penelitian ini yaitu berjumlah 51 orang. Data dalam penelitian ini dengan teknik sekunder yaitu data yang diperoleh dari catatan yang ada di Puskesmas (register pasien). Analisa data secara univariat.
HASIL

\section{Analisa Univariat}

Tabel 1 Gambaran distribusi frekuensi pneumonia pada batita menurut umur, jenis kelamin dan berat badan.

\begin{tabular}{lcc}
\hline \multicolumn{1}{c}{ Variabel } & $\begin{array}{c}\text { Frekuensi } \\
(\mathbf{N = 5 1 )}\end{array}$ & $\begin{array}{c}\text { Persentase } \\
(\mathbf{1 0 0 \% )})\end{array}$ \\
\hline Umur & 31 & 60,8 \\
13-24 bulan & 20 & 39,2 \\
25-36 bulan & & \\
Jenis Kelamin & 37 & 72,5 \\
Laki-laki & 14 & 27,5 \\
Perempuan & & \\
Berat Badan & 29 & 56,9 \\
Kurus & 22 & 43,1 \\
Normal & & \\
\hline
\end{tabular}

Tabel 1 dapat dilihat bahwa sebagian besar $(60,8 \%)$ anak berumur 13-24 bulan, sebagian besar $(72,5 \%)$ anak berjenis kelamin laki-laki, dan sebagian besar $(56,9 \%)$ anak berada dalam kategori berat badan kurus.

\section{PEMBAHASAN}

Hasil penelitian didapat bahwa sebagian besar $(60,8 \%)$ anak berumur 13-24 bulan, hal ini dikarenakan pada usia ini merupakan masa golden age yaitu 1-3 tahun dimana pada masa tumbuh kembang ini anak rentan terhadap infeksi dan penyakit khususnya pada saluran pernapasan dan pencernaan. Berdasarkan panduan stimulasi, deteksi dan perkembangan anak pada anak usia 13-24 bulan dengan perkembangan normal, pada sektor motorik halus, anak baru dan bisa menggenggam benda-benda yang anak temui, sehingga anak rentan memasukkan benda yang anak genggam kedalam mulutnya yang dapat memperbesar resiko masuknya bakteri/infeksi kedalam tubuh anak terutama saluran pernapasan dan pencernaan (Depkes RI, 2006).

Selain itu dari segi makanan yang anak konsumsi, pada usia 13-24 bulan anak tetap diberikan ASI dan baru diberikan makanan pendamping seperti makan nasi, dan menginjak usia 13 bulan bayi mulai diperkenalkan makanan keluarga mengganti makanan pendamping asi seperti bubur, tepung beras, bubur encer, pisang lumat dan pepaya lumat (Amalia, 2006). Baru diperkenalkannya a- 
nak dengan makanan keluarga sering kali menyebabkan anak mengalami perubahan selera makan, sehingga anak akan cenderung menerima saja makan apa yang diberikan kepada anak. Kebiasaan seperti ini sering kali menyebakan orang tua memberikan makan yang disukai tidak pandang itu bahaya atau bukan terhadap tubuh anak, seperti permen, coklat, snack, dan kerupuk. Pemberian MP-ASI yang salah ini beresiko terhadap kesehatan anak terutama pada saluran pernafasan, dengan gejala yang sering muncul adalah batuk (Aziz, 2008).

Hasil penelitian bahwa sebagian besar $(72,5 \%)$ batita yang menderita pneumonia berjenis kelamin laki-laki. Kejadian pneumonia pada anak laki-laki lebih berisiko dengan perbanding 2:1 karena pada anak perempuan maturasi serebral yang terjadi lebih cepat pada anak perempuan dibandingkan pada anak laki-laki, sehingga ketika ancaman penyakit masuk kedalam tubuh anak perempuan, reaksi tubuh anak perempuan lebih cepat menangkalnya (Aziz, 2008).

Hal ini diperkuat oleh pendapat Soetjiningsih, 2007 yang memaparkan bahwa terdapat perbedaan pola aktivitas pada anak laki-laki dengan anak perempuan, karena pada anak laki-laki pola aktivitasnya lebih aktif sehingga fisik anak cenderung lebih cepat lelah dan menurunnya daya tahan tubuh anak, sehingga beresiko masuknya infeksi ataupun bakteri. Aktivitas pada anak laki-laki cenderung lebih aktif, seperti bermain baik di dalam rumah maupun dilingkungan, pada anak usia batita kegiatan bermain merupakan kegiatan yang berdampak positif karena dapat menjadi stimulus perkembangan anak, dampak yang positif ini dapat terjadi jika kegiatan bermain anak dapat dihandle oleh orang tua karena jika aktivitas ini tidak diatur sedemikian rupa maka akan memberikan dampak negatif

\section{DAFTAR RUJUKAN}

Anik, 2010, Ilmu Kesehatan Anak dalam Kebidanan,Trans Info Media, Jakarta pada anak, karena anak kelelahan dan menurukan daya tahan tubuhnya.

Hasil penelitian didapat bahwa sebagian besar $(56,9 \%)$ anak berada dalam kategori berat badan kurus. Berat badan anak sangat dipengaruhi oleh status gizi anak, khususnya pada anak yang malnutrisi, yang berakibat menurunya kekebalan tubuh anak terhadap penyakit (infeksi) baik yang disebabkan oleh virus, bakteri maupun fungi (Cuningham, 2006).

Faktor-faktor yang mempengaruhi berat badan anak berada dalam kategori kurus dapat berupa pola makan yang salah, penyediaan pangan yang kurang karena status ekonomi keluarga, jumlah anggota keluarga, dan lingkungan (Aziz, 2008).

Masa batita merupakan masa pertumbuhan dan perkembangan yang pesat, sehingga kerap disebut sebagai periode emas sekaligus periode kritis. Periode emas dapat diwujudkan apabila pada masa ini bayi dan anak memperoleh asupan gizi yang sesuai. Sebaliknya apabila bayi dan anak pada masa ini tidak memperoleh makanan sesuai kebutuhan gizinya, maka periode emas akan berubah menjadi periode kritis yang akan mengganggu kesehatan dan tumbuh kembang anak, baik pada saat ini maupun masa selanjutnya (Nutrisiani, 2010).

\section{KESIMPULAN}

Berdasarkan hasil penelitian maka dapat disimpulkan: Sebagian besar anak yang menderita pneumonia berumur 13-24 bulan, sebagian besar anak yang menderita pneumonia berjenis kelamin laki-laki, sebagian besar anak yang menderita pneumonia berada dalam kategori berat badan kurus.di wilayah Kerja Puskesmas Sukamerindu tahun 2014.

Puskesmas Sukamerindu diharapkan dapat memberikan informasi pencegahan pneumonia yang bermanfaat bagi masyarakat.

Arikunto, Suharsimi. 2006. Manajemenpenelitian. Jakarta :RinekaCipta 
Almatsier. S.2005. Prinsip Dasar Ilmu Gizi. Gramedia Pustaka Utama. Jakarta.

Aziz Alimul, A. 2008. Pengantar Ilmu Kesehatan Anak Untuk Pendidikan Kebidanan, Jakarta: Salemba Medika

Depkes RI, 2009, Pneumonia sebagai Penyebab Kematian Bayi. Jakarta

Ganda, 2011. Karakteristik Penyakit Pneumonia pada Anak di Ruang Merpati II RSU Herna Medan Tahun 2011. Karya Tulis Ilmiah Stikes Bakti Bangsa Medan. Diakses pada 1 Maret 2014.

Hartati, 2011. Analisis Faktor Resiko Yang Berhubungan Dengankejadian Pneumonia Pada Anak Balita di RSUD Pasar Rebo Depok Tahun 2011. Tesis Magister Ilmu Keperawatan Universita Indonesia Tahuin 2011. Diakses pada 6 Maret 2014.

Hidayat. 2008. Pengantar Ilmu Kesehatan Anak untuk Pendidikan Bidan. Jakarta: EGC.

Kemenkes, 2011, Proporsi Kematian Bayi Pada Bayi Balita Pneumonia. Jakarta

Mansjoer, Arif. 2009. Kapita Selekta Kedokteran Jilid : Edisi 3. Media Aesculapius. Jakarta

Mauli, 2014. Karakteristik Balita Yang Menderita Pneumonia di Wilayah Kerja Puskesmas Kota
Sigli Kabupaten Pidie Tahun 2014. Jurnal Karya Tulis Ilmiah STIKes U'Budiyah Banda Aceh D-III Kebidanan. Diakses pada 6 Maret 2014.

Ngastiyah, 2005, Perawatan Anak Sakit, Penerbit Buku Kedokteran EGC. Jakarta.

Notoatmodjo, 2005. Metodologi Penelitian Kesehatan. Rineka Cipta. Jakarta.

Prawirohardjo, 2009, Pelayanan Kesehatan Neonatal dan Maternal. Jakarta: Yayasan Bina Pustaka

Siswanto, Hadi, 2010. Pendidikan Kesehatan Anak Usia Dini. Yogyakarta : Pustaka

Soetjiningsih. 2007. Buku Ajar Tumbuh Kembang Remaja dan Permasalahannya. Jakarta : Sagung Seto

Suhardjo. 2009. Berbagai Cara Pendidikan Gizi. Bumi Aksara. Jakarta

Suryadi, 2008. Asuhan Keperawatan Pada Anak. Jakarta : EGC

Supariasa.2010. Penilaian Status Gizi. EGC. Jakarta Wilson, 2006, Etiology Of Pneumonia, American Journal diakses pada 24 januari 2014.

WHO, 2010, Manifestation Of Pneumonia. 